UDC 330.341.1:338.48:005.332.2(477.87)

DOI : http://doi.org/10.31617/k.knute.2020-06-01.26

Petro Havrylko,

Ph.D., Professor, Director of

Uzhgorod Trade and Economic Institute of the Kyiv National University of Trade and Economics ORCID: 0000-0002-8917-5063

Anatoliy Kolodiychuk,

$\mathrm{PhD}$, Associate Professor of

Uzhgorod Trade and Economic Institute of the Kyiv National Trade and Economic University ORCID: 0000-0001-5727-0560;

Tetyana Hushtan,

Ph.D. of Economics, Associate Professor, Uzhgorod Trade and Economic Institute of the Kiev National Trade and Economic University ORCID: 0000-0002-4005-9029

\title{
POTENTIAL OPPORTUNITIES FOR TOURISM DEVELOPMENT IN TRANSCARPATHIA AND THE MEASURE TO WHICH MODERN ICT TECHNOLOGIES PENETRATE INTO IT
}

The paper identifies and characterizes potential opportunities for the development of tourismin the Transcarpathian region and determines the degree of penetration of modern information and communication technologies in it. The resort areas of Transcarpathia have been identified and its natural and recreational potential is analyzed. The features of ski tourism development in the region are considered. The existing conditions for the development of urban tourism in the Transcarpathian region are investigated. Based on the theory of network organizations, the systematic orientation of the processesof informatization flowfor sanatorium and resort establishments of the Transcarpathian region is substantiated and proved.

Keywords: tourism, financing, progress, recreation, region, resort potential, ICT, urban tourism, theory of network organizations.

Relevance of research topic. The sanatorium and resort economy remains a key component of the tourism and recreational potential of the Transcarpathianregion. New establishments appear every year, and all relevant infrastructures are being built. In this regard, it becomes important to study these modern processes and to clarify the role of information and communication technologies in them. 
Formulation of the problem. With the development of resort and tourist management systems, sanatorium and resort treatment in the tourist complex is becoming increasingly important. Transcarpathia, with significant natural resource, healing, health and recreational potential, is at the forefront of this problem among the regions of Ukraine.

Analysis of recent research and publications. Many scientists have contributed to the formation and development of the theory of network organizations, on which the entire system of informatization of the sanatorium and resort complex of the Transcarpathian region can base oneself on, among which the scientific works of M. Armstrong, I. Burdyanovsky, F. Herzberg, E. Giddens, G. Emerson, O. Ermansky, M. Castels, R. Quinn, G. Saymond, L. Smith-Dory, L. Urvik, and others. At the same time, the general outlines of the organization of an integrated system of informatization of the sanatorium-medical complex of the Carpathian and Transcarpathian regions are poorly outlined, taking into account the specific features of the local tourist and recreational potential.

The purpose of the paper is to identify the main components of the tourism and recreational potential of Transcarpathia and to find out the degree of penetration of ICT technologies in it.

Presenting main material. It is possible to distinguish the following resort areas in the Transcarpathian region: 1) Svalyava-Mukachevo; 2) Mizhhir»ya; 3) Rakhiv-Khust. The first includes sanatoriums «Carpathians», «Synyak», «Polyana», «Sunny Transcarpathia», «Constellation», «Flower of the Valley», «Crystal Spring», «Pearl of the Carpathians»; the second consists of the Verkhovyna health resort; the third - «Mountain Tysa» and «Shayan». However, as noted by H. M. Zavarika, due to organizational deficiencies of management, moral and physical deterioration of the material and technical base, lack of financing, low competitiveness of self-financing enterprises, a considerable part of sanatorium and resort establishments is unprofitable, and therefore this segment of tourism and recreation is experiencing a deep crisis today [4, p. 15].

In the Svalyava-Mukachevo district the rare mineral springs Luzhanska 4, Luzhanska 7, Luzhanska 12, PolyanaKupel, Ploskivska, Kelechynska, Soymy, Drahivska, Shayanska and Polyana Kvasova. These carbonic hydrocarbonate, hydrocarbonate-chloride mineral waters which, by their physicochemical properties (in particular, for sodium bicarbonate), are close to the well-known foreign waters of Borjomi, Vichy, Yessentuki, Narzan, Matsesta and become the key therapeutic factor of the whole resort potential of Transcarpathia. The healing properties of Polyana Kvasova in the treatment of gastric diseases, respiratory disorders, diabetes and atherosclerosis have been revealed, and are not inferior to Naftusya of Truskavets in the treatment of diseases of the urinary tract. In Transcarpathia, about 360 deposits of healing mineral waters were discovered and explored.

Equally important for the development of recreation are the natural conditions of the region. The geographical features of the territory of the region are as follows: 
about $2 / 3$ of the area of the region is occupied by mountains and only a third - the Prytysyanska low land. The mountain part consists of the ridge and massifs systems of the Eastern Carpathians, including four ridges - Polonynsky (including Borzhavsky massif), Verkhovyna, Volcanic and Aquarius, as well as four mountain massifs of Gorgany, Svydivets, Rakhiv massif and Chornohoramassif. The highest peak of Ukraine-Mount Hoverla (2061 m) is also localized in the Transcarpathian region. In addition, the territory of the region from the northeast slopes of the Carpathian Mountains, which are located in the neighboring regions, is separated by a network of passes: Uzhotsky, Volovetsky, Veretsky, Yablunetsky, Torunsky, Legions, up to a kilometer above sea level. The village of Dilovo in the Rakhiv district, where the geographical center of Europe is located, is also tourist attraction in Transcarpathia. Region is also rich on water resources. Thus, more than 9.5 thousand rivers and streams flow through its territory, including the Tysa, Uzh, Latorytsya, Rika, Teresva, Tereblya, Borzhava, as well as nearly one and a half hundred lakes of natural origin, the largest of which is Synevyr Lake in Mizhgirsky district.

Temperate continental climate of the region contributes also to the recreation. The average temperature amplitude ranges from $+21^{\circ} \mathrm{C}$ in summer to $-4^{\circ} \mathrm{C}$ in winter. There are three national parks in the region: Uzhansky (VelykoBereznyansky district), Synevyrsky (Mizhgirsky district) and «Enchanted land» (Irshavsky district). Among the natural attractions that are attractive to tourists are the following: the Valley of Narcissus near Khust, the Ugolsko-Shyrokoluzhansky mountain massif as the largest center of beech wildwoods on the European continent, the miraculous cross in the Church of Church of St. Elijah invillage Chynadiyevo, salt lakes near the village Solotvyno, waterfall Shypit near the Gemba mountain in the Polonyna Borzhava massif, Yalynsky waterfall in the Rakhiv mountains, Trufanets waterfall in the Svydivets massif in Rakhiv region, Lumshore waterfalls in Perechyn region (in particular, Nightingale, Davor, Burkach, Krutylo), Skakalo waterfall within the Vygorlat-Hutyn volcanic massif in the Mukachevo district, the cascade Kamyanetsky waterfall (Synevyr) in the Inner Gorgany massif, the cascade Drahobratsky waterfall in the Svydivets massif, the Vyshovaty waterfall, the Voyevodyn waterfall in the massif Polonyna Runa, Horodylivsky waterfall in the massif Dull and more. The Ukrainian State Allergology Hospital is located in Solotvyno, which is the deepest medical institution in Ukraine [6, p. 390], established in 1986 on the basis of Uzhgorod branch of the Odesa Research Institute of Balneology for the treatment of patients with bronchial asthma. The region is characterized by well-developed flora, with more than two thousand species. In the foothills, in the lowlands are acreage, gardens, vineyards, meadows, oakforests, beech forests, in the east of region are coniferous forests ( $1 / 4$ forest area). Visiting the Transcarpathian flora is the high alpine meadows -mountain meadows, with lush grassy cover.

Equally important are other man-made components of Transcarpathia's tourism and recreational potential - cultural historical monuments. In particular, it is the 
Palanok Castle in Mukachevo, the Nevitske Fortress in Uzhgorod, the Holy Cross Cathedral in Uzhgorod, the Komitatsky House and the Goryanska Rotunda in Uzhgorod, the Palace of the Counts of Schoenborn, namely White Palace in Mukachevo, Shelestivska St. Michael's Church in Uzhgorod, the court yard and the palace of Prince G. Betlen in Berehove, Franciscan Monastery and Ascension Church in Vynohradiv, Baron Pereny's Estate in Vynohradiv, Shenborn's Palace in Chynadiyevo, Reformed Church in Tyachiv, Khust Castle, Palace-Fortress in the village Dovhe in the Irshava district and others.

Another type of tourism in Transcarpathia is the ski tourism. Snow height in the Carpathian Mountains is on average $70-80 \mathrm{~cm}$, which allows to development the skiing and other winter recreation in the region. In recent years, there has been an increase in the number of ski centers and rental points in the region. Thus, in preparation for the 2022 Winter Olympicsin the Carpathian Mountains, investment projects are being implemented for the construction of skiing complexes in the area of the village Yasinya-Polonyna Dragobrat and the village Kvasy-Blyznytsya Mountain, skiing complex Borzhavski Polonyny, creation of Petros Mountain Resort (named after the mountain of the same name), Uzhgorod-Polonyna Runa Complex. These investment projects include the formation of a network of new hotels, restaurants, bars, cafes, fast foods, snow parks, water parks, spas and wellness centers, ski slopes and lifts, parking lots, golf courses, boarding houses, cottages and more. The main existing and functioning centers of ski tourism in the region are Pylypets, Yasinya, Dragobrat, Polyana, eco-resort Izky, Vyshka, Mizhgirya, Podobovets. Among the services, in addition to skiing, there are also ski-tours, snow tubing (chewing on cheesecakes unmanaged rubber wheels with a solid bottom), sledding, freeriding (snowboarding and skiing), ratraks (special preparation of ski runs for skiing), après ski, rental services and more. Separate types of free ride are also available, in particular: back country (climbing to the tops (mount Hoverla) on laid routes - skayturs), heli-skay (throwing skiers to the top of the mountain by helicopter with subsequent self-descent) is not available due to high prices, although quad bike rental are offered.

In addition, it should be noted that the highest and most extreme (in the nature of the ski slopes) ski resort for trained skiers is Dragobrat, the longest route 3,5 km long on Mount Krasia in the resort Vyshka, which is also the longest in Ukraine ski slope. Less well-known liftson the basis of hotel complexes are successfully operating, in particular boogles on the territory of the sanatoriums Synyak, Mountain Meadow Flower, in the village of Osiy and in Lumshory. There are also training centers for skiing tourists. Thus, the ski school and the snowboard school function based on Pylypets resort. They offer snowboarding and skiing techniques, jibbing programs, foggles (downhill jumping from a special ski jump), ski cross (skiing at speed with turns), ski-halfpipe (skiing flip, flips, freestyle), ski-slopestyle (passing with obstacles: jumps, quarterpipes and rails).

We will go into more detail on the development of urban tourism in Transcarpathia. In the region there are five cities of regional importance - Uzhgorod, 
Mukachevo, Khust, Berehovo and Chop, as well as six cities of district importance Irshava, Perechyn, Svalyava, Tyachiv, Rakhiv and Vynogradiv. These eleven cities have the tourist potential of the mentioned profile, among which the leading cities are Uzhgorod and Mukachevo. The main tourist attraction of the city of Uzhgorod is the thousand-year-old castle, which is now the Transcarpathian Regional Museum of Local History named after T. Legotsky. It has the shape of an irregular quadrangle, and the castle complex itself consists of a palace, actually defense structures, fortress underground, the remains of the ancient church of St. George, a series of original sculptures and five parks (Meadow, Flower, Animal, Cranberry, Blueberry). Modern digital technologies are also being introduced: virtual 3D tours exist both in Uzhgorod Castle and in other places of interest in Uzhgorod. In the city there is the most developed restaurant complex in the region (Uzhgorod Castle Restaurant, Mrs. Greenwich's Mezzanine Cafe, restaurants Detsain Notary, Cactus, Charda, Venice, Corso 10, Bondarenko Confectionery, etc.). In the context of urban tourism in the city and its surroundings, the main are the following sites: Nevytsky Fortress (10 km from Uzhgorod Castle), botanical garden (since 1945, about 6000 species of plants are represented in the garden), Holy Cross Greek Catholic Cathedral, Synagogue, Brewery Owl's Nest, Transcarpathian Art Museum named after Bokshay, Gallery ILKO, Gorian Rotunda - Church of St. Annie. As in Uzhgorod, the key tourist center in Mukachevo is also the Palanok Castle-Fortress, which was founded in the XI century. Since 1960, there is a historical museum. Compared to Uzhgorod's monuments, information and communication technologies are somewhat behind: only recently the castle and its surroundings are present in the Google Street View program mode for panoramic street view. Important tourist attractions in the city are: Mukachevo Town Hall, Rakoczi Princes' Palace, St. Nicholas Monastery, Roman Catholic Church of St. Martin, and Assumption Greek Catholic Cathedral. There are two tasting tourist sites in the city: farmstead Celtic Yard Near Lovachka, where ale, apple cider, gin, grappa, grass vermouth (original Boudicca and Sacred Grove brands), schnapps are tasted; Honey House, which is a part of the Transcarpathian honey route, where are presented 4 types of local honey, honey samples from 27 countries, medovukha and herbal balm. The annual Red Wine Festival is held in Mukachevo, and the festival of flowersis held regularly in the St. Miklosch Castle near Mukachevo. Own tourist information center (Mukachevo TIC) has been established and operates for coordination of the routes of tourists in the city, which mainly catalogs the city's tourist sites and provides background information to visitors of the city. However, this TIC does not yet have its own internet site, except for the Facebook page.

The city of Khust, like Uzhgorod and Mukachevo, also had its castle in the 11th-18th centuries, but only ruins remain from it. However, it is also a tourist attraction, as it houses the Khustsky Castle Nature Park, in which houses the historic cemetery. In addition, it is a valuable attraction of sacred tourism because the heroes of the Carpathian Ukraine are buried there. The city adorns the Czech quarter, built in the 1920s in chalet architectural style. Traditionally attractive also religious buildings: the 
Reformed Church of St. Elizabeth, Church of St. Annie. Also interesting for tourists are the deer farm, buffalo farm and ostrich farm, and the real natural gem of the outskirts of the city is the Khust Valley of Narcissus. A significant problem of local tourism is the neglect of tourist sites - historical cultural monuments that may be lost over time; on the other hand, there is a relatively small number of monuments, but there are great opportunities for the development of rural, forest, recreational (which, incidentally, is offset by the localized nearby sanatorium «Shayan»), winter, mountain, rafting (alloys along the river Tysa to Vynogradivare organized) types of tourism. The small town of Irshava is represented by the Enchanted Land National Park, the SmerekovyStone Tract, the Dovgai Family's Palace, the 300-year-old forge museum of Gomora; such monument of vintage rail tourism as the Borzava Narrow Gauge Railway, built over 100 years ago during the Austro-Hungarian period. Notable tourist attractions in Beregovo are: Beregovo «humpbacked» bridge over the Verke Canal, Count court - the palace of Count Betlen, Lord's casino «Golden Peacock», Roman Catholic Church of the Exaltation of the Holy Cross on Sq. Ferenc Rakoczi II, twin palaces of Meigesh and Kubovych. Water tourism is especially developed in this city. There is a terminal-water park «Maximus», and the famous thermal waters of the Beregovo are known throughout Ukraine. Wine tasting tourism is not far behind as well, there are two tasting rooms: Chizay and Lark. In the cities of the region there is also widespread tasting tourism: Tasting Hall of honey and beekeeping products in Mukachevo, tasting room of wine «Old Cellar» in Beregovo, wine tasting room in Uzhgorod. With regard to the wine tasting segment, such facilities tend to be located in Transcarpathian wineries located mainly in cities. Internet advertising of these objects is very poor today. The main problem in the sphere of urban tourism in Transcarpathia remains the lack of a systematic approach that would combine all tourist sites into a single tourist system, in this direction only discussions are being held on the creation of tourist clusters Uzhanska Valley, Uzhgorod City and Vicinity; poor investment climate due to unresolved organizational issues in the development of the tourism sector does not contribute to attracting serious investors, such as in Lviv; local authorities not establishedproper public relations; despite the considerable tourism potential of the cities in the region, a quality tourist product is essentially absent. This all puts a negative mark on the economic status (low profitability) of the tourism companies operating in the region.

In the modern world, in the age of planetary transition from neo-Keynesianism to economic neoliberalism, the traditions of bureaucratic governance are being actively not used, replaced by e-commerce and other types of Internet technologies. In this respect, the centers of provision of sanatorium-medical, resort-health, as well as tourist services are no exception; the increasing scale of IT implementation and adaptation of e-communications in them is the key to increasing the level of systematic management of this area based on these centers. In our opinion, the theory of networking organizations can and should serve as the theoretical basis for the flow of these newest 
processes in such a segment of the service sector as tourism and recreation. Based on the definitive characteristics of this theory, the network core is the PJSC of medicalhealth institutions of trade unions of Ukraine «Ukrprofozdorovnytsya», as well as the administration of the institutions themselves (within the region are: sanatoriums «Verkhovyna», «Polyana», «Carpathians», «Sunny Zakarpatya» «Shayan», «Flower of the Valley», «Synyak», «Crystal Spring»). At the national level, the company «Ukrprofozdorovnytsia» includes more than 80 resort health institutions, which serve a total of 0.5 million people every year. The main staff of the system of health resorts in the regioncan be considered as the first peripheral network layer, as an intermediate link between the core and temporary employees (orderlies, waiters, trade in the sanatorium, etc.). The second peripheral network layer is the transit, temporarily hired staff of sanatoriums, resort and wellness establishments. It is theoretically established that the bearers of organizational network culture are the very core of the institutional community; therefore, it is at their disposal that there is a region-wide process of ICT implementation in the segment of use of tourism and recreational potential of subordinate territories, and not only the development of information culture as a type of organizational culture among employees of reporting establishments and subsidiary organizations of different profiles. This is confirmed by the fact that nowadays PJSC «Ukrprofozdorovnytsya» currently has 60 mineral water deposits and a dozen centers of healing mud. The motivation of the network kernel is that it is an opportunity for self-realization, the motivation of the peripheral layer of our network organization - in the possibility of improving and unification of the established routine of work of institutions, the motivation of the II peripheral layer of the network community - in improving the conditions for being in the organization. As we can see, the established «rules of the game» take due account of the existing level of subjectivity of workers and interested social groups of the population, make it possible to increase the flexibility of the organization of work as a whole, and the separate introduction of schemes of tariff bits of flexible employment. In the end, it will allow to properly segment the market of sanatorium and resort services, to introduce effective programs of staff development, to improve its organizational (including information) culture along with the development of skills. This also applies to related organizations. A typical example is the developed information portal [6] located near the Uzhgorod sanatorium complex «DerenivskaKupil». For the second network layer, it is at least possible to offer the development and launch of a bot-chat recruiter, which allows to quickly and effectively filling vacancies for jobs based on the newest foundations in the HR environment in the temporary workforce market. Often, they look for potential employees on social networks - in WhatsApp, Facebook, LinkedIn, Pinterest, MeetUp, MeetMe, Telegram and more. A concrete example is the D.TalCa bot recruiter [2], which works with clients at Telegram at the world-renowned company Deloitte in Ukraine. There are opportunities to automatically connect employers to already-functioning chatbots. In order to do so, they need to submit their FAQ (a list of job applicant questions - interview) on behalf of their organization and enter it into 
database for processing by a bot. In the future, the theory of network organizations confirms and develops the so-called process of McDonaldization [9], as a modern manifestation of adaptive rationality, as opposed to the theory of rational expectations, when the principles of work of the same name restaurant apply to different spheres of life of population (education, tourism, policy).

Conclusion. Thus, the analysis of components of the tourism and recreational potential of the Transcarpathian region showed that some of them are not realized enough (historical and cultural heritage), others are experiencing stagnant phenomena in their development due to insufficient state financial support and lack of quality investment proposals (sanatorium-resort sector) and segments such as snow tourism have been developing rapidly in recent years. In our opinion, rural green tourism, bike and extreme tourism should also be developed in Transcarpathia, which is facilitated by natural climatic and landscape conditions. At the background of diversification of types of tourist and recreational activity in the region, the issues of systematic informatization of the industry as a whole, elaboration of common rules and standards, strengthening of communication between the constituent elements of this regional information system are of particular importance at this stage.

\section{REFERENCES}

1. Babkin, A. V. (2008).Spetsial'nyye vidy turizma [Special types of tourism]: Tutorial. Rostov-on-Don: Phoenix. [in Russian].

2. Bot-rekruterD. TalCa [D. TalCaBotRecruiter] (2020).Deloitte in Ukraine: Website. Retrieved from https://www2.deloitte.com/ua/uk/careers/chat-bot-dtalca-atdeloitte-ukraine.html?icid=top_chat-bot-dtalca-at-deloitte-ukraine. [in Ukrainian].

3. Zhukova, M. A. (2006). Menedzhment v turistskom biznese [Management in the tourism business]. Moscow: KNORUS. [in Russian].

4. Zavarika, H. M. (2015). Kurortna sprava [Resort business]: Tutorial. Kyiv: Center for Educational Literature. [in Ukrainian].

5. Malska, M. P., \& Khudo, V. V. (2007). Turystychnyy biznes: teoriya ta praktyka [Tourist business: theory and practice]: Textbook. Kyiv: Center for Educational Literature. [in Ukrainian].

6. Sanatornyy kompleks «Derenivs'ka kupil'« [Sanatorium complex «Derenivska Kupil»]: Official web-portal (2020). Retrieved from https://derenivska-kupil.ua/ [in Ukrainian].

7. Pysarevskyy, I. M. (Ed.), Pohasiy S. O., \&Andrenko I. B., et al. (2008). Orhanizatsiya turyzmu [Organization of tourism]: Textbook. Kharkiv: KhNACE.[in Ukrainian].

8. Petranivskyy, V. L., \&Rutynskyy, M. Y. (2006).Turystychne krayeznavstvo [Tourist local history]: Tutorial. Kyiv: Knowledge. [in Ukrainian].

9. Ritzer, J. (2011). Makdonal'dizatsiya obshchestva [Macdonaldization of society]: Translated from English. Moscow: Praxis. [in Russian].

10. Sokol, T. H. (2009).Orhanizatsiya obsluhovuvannya v hotelyakh I turystychnykh kompleksakh [Organization of service in hotels and tourist complexes]. Kyiv: Alterpress. [in Ukrainian]. 